\title{
LUTHER IN MELANCHTHON O ŠOLI, UČITELJU IN IZOBRAŽEVANJU
}

\section{Marko Kerševan \\ Uvodno pojasnilo}

Za tokratno rubriko Prevod (protestantskih besedil, ki so ali naj bi "pustila sledove $\mathrm{v}$ zavesti in ravnanju) smo tokrat izbrali dva spisa, enega Martina Luthra in drugega Philippa Melanchthona, ki govorita o šoli, izobraževanju in učitelju. Povodov in razlogov za prevod (odlomkov) teh spisov letos - in ne le letos - ne manjka. V letu 2019 slavimo 1oo-letnico ustanovitve ljubljanske univerze, prve nesporno slovenske in nesporno univerzitetne ustanove na naših tleh - po starejših začetkih in vmesnih dosežkih, do katerih je prišlo nenazadnje prav zaradi duha, ki ga je izražala in spodbujala protestantska reformacija. Drugi povod/razlog je prav letos oživljena razprava o »kaj, kako in čemu« osnovnošolskega izobraževanja v našem sedanjem času in prostoru.

Obe besedili govorita o izobraževanju v smislu, ki ga v nemškem jeziku obeh reformatorjev nosi s seboj beseda Bildung in ki je (zato) izvorno etimološko tudi v naši iz-obraz-bi. Bildung oziroma izobrazba/ izobraževanje ni bila/-o mišljena/-o le kot pridobivanje in pridobitev znanja, vedenja, ampak tudi kot hkratno oblikovanje človekove podobe/ obraza, formiranje njegove osebnosti. V slovenskem jeziku se je pomen izraza izobrazba/izobraževanje sčasoma tako zožil na znanje in pridobivanje znanja, da je postala potrebna sintagma »vzgoja in izobraževan- 
je«, da bi vsaj približno ohranili izvorni pomen in namen Bildung oziroma izobrazbe.

Oba skoraj petsto let stara spisa seveda izhajata iz razmer njunega časa, govorita o njih in iz njih. Toda oba sta hkrati izraza in nosilca duha (humanizma, reformacije), ki je takratne razmere spreminjal in jih - skupaj z drugimi dejavniki, seveda - na dolgi rok tudi uspešno spremenil. Slednje lahko rečemo kljub nekaterim prevelikim pričakovanjem in iluzijam, ki jih srečamo $\mathrm{v}$ teh pionirskih besedilih (in ki so v pionirskih besedilih sploh pogosta). Oba spisa lahko tako jemljemo kot zgodovinska/spominska, saj nam govorita, iz česa in kako sta nastajala sodobno izobraževanje in sodobno šolstvo; toda prav zato sta obe besedili lahko tudi opomin in opora (svarilo ali spodbuda) pri soočanju s sodobno ogroženostjo osnovnega izobraževanja na eni in visokega šolstva na drugi strani. Ogroženost je, kot vemo, pogojena tako »objektivno« kot »subjektivno «: z objektivnimi spremembami pogojev in kontekstov pridobivanja znanja (internet itd.) in s spremenjenimi pogledi na namen in pomen izobraževanja, šole in učitelja. Ogrožajoče pri tem niso same spremembe oziroma kakršnekoli spremembe, ampak tiste, ki ogrožajo tako osnovno kot visoko šolstvo pri njuni izvorni nalogi: nerazdružnemu povezovanju pridobivanja znanja in usposabljanja zanj ter formiranja osebnosti - osebnosti, ki bi rasla s pridobivanjem (in ustvarjanjem) znanja, in pridobivanja znanja, katerega gibalo bi bila radovedna, iščoča in ustvarjalna osebnost.

Ni slučajno, da je Luthrov spis iz leta 1524 usmerjen predvsem $\mathrm{k}$ osnovnemu, temeljnemu izobraževanju vseh, Melanchthonov pa k višjemu šolstvu. Ni slučajno, da je Luthrov v sočni nemščini napisani nagovor mestnim oblastem poln sklicevanja na svetopisemska besedila, na zglede in opomine prerokov in apostolov, v Melanchthonovi latinski oratio pa srečamo ob Salomonu (imena) Platona, Cicera, Hesioda, Evripida, Scipiona. Luther je bil reformator temeljev (vere, cerkve in posredno družbene ureditve) in zavedal se je, da temeljev ni mogoče reformirati brez temeljne/osnovne izobrazbe vseh (vernikov), v njegovem času predvsem (otrok) kmečkih in mestnih plebejskih množic njegovih »ljubih Nemcev«, ob hkratni nuji, da se izobrazijo tudi (bo- 
doči) vodilni in vladajoči; pri enih in drugih poudarja pomen široke izobrazbe, »zgodovine« in »matematike«. Melanchthon, sam vrhunski humanistični izobraženec in univerzitetni profesor klasičnih jezikov, utemeljitelj moderne nemške/srednjeevropske gimnazije, Praeceptor Gemaniae, »Učitelj Nemčije«, ${ }^{1}$ meri predvsem na univerzo in univerzitetnega učitelja. Seveda je dobro poznal tudi »revščino učiteljev« (ne le njegovega časa): »dninar je bolje plačan kot učitelj«, je zapisal; primerjal je učitelja s Sizifom, ko se »brezuspešno muči, da bi premagal pomanjkanje motivacije pri učencih«; že pred spisom, iz katerega objavljamo odlomke, je leta 1533 napisal tudi »Govor o trpljenju učiteljev«, De miseriis paedagogorum oratio; toži o neustrezni motivaciji za študij, ko imajo prednost finančni vidiki pred vsebino in temeljno izobrazbo, tako da študenti s preslabo predizobrazbo "vdirajo v najresnejše in najplemenitejše študije kot svinje v vrtnice«. Pa vendar je leta 1536 kljub temu (ali prav zato) hotel in zmogel napisati pravo apoteozo šole in učiteljskega poklica nasploh in visokošolskega še posebej. Naj bo njegova laudatio/hvalnica, opora in spodbuda tudi učiteljem slovenske univerze ob njeni stoletnici, naj bo njegov nagovor sprejet kot izziv k odgovoru, kot poziv k najboljšemu odgovoru, ki je po Melanchthonu $\mathrm{v}$ kar največji odgovornosti in hkratnem največjem zadovoljstvu pri opravljanju svojega dela kot poklica(nosti).

1 O Philippu Melanchthonu (1497-1560), Luthrovemu najtesnejšem sodelavcu, piscu Augsburške veroizpovedi (1530) in njene Apologije (1531), smo v reviji pisali ob 450-letnici njegove smrti, ko smo prevedli odlomke Apologije (glej Stati inu obstati 11-12/2010, str. 236-80). K tam navedeni literaturi o njem dodajmo še dve biografski deli: Heinz Scheible, Melanchthon: Eine Biographie (München: Beck, 1997) in Hans-Rüdiger Schwab, Philipp Melanchthon: Der Lehrer Deutschland; Ein biographisches Lesebuch (München: DTV, 1997), od koder so tudi sledeči navedki. 


\section{Martin Luther \\ Mestnim svetnikom vseh mest nemške dežele, da morajo ustanavljati in vzdrževati krščanske šole, $1524^{2}$ \\ [izbor odlomkov]}

Kaj bi nam pomagalo, če bi imeli vse in bili kot brezmadežni svetniki, a bi opustili to, za kar predvsem živimo: da namreč poskrbimo za mlade? Menim tudi, da noben zunanji greh ne obremenjuje sveta bolj in noben ne zasluži ostre kazni bolj kot tisti, ki ga storimo nad otroki s tem, da jih ne vzgajamo. [...] »Seveda«, lahko rečeš, »to je treba reči staršem, toda kaj imajo s tem mestni svetniki in oblast? « Gotovo, res je. Toda kaj, če starši za to ne poskrbe? Kdo bo to storil? Ali se lahko oblast, mestni svet opraviči, češ da to ni njegova naloga?

Da za to ne poskrbe starši, je več vzrokov.

Nekateri se enostavno ne zavedajo dolžnosti, da bi to storili, čeprav bi to zmogli. Kot noji se obnašajo do lastnih otrok: zadovoljijo se s tem, da znesejo jajca oziroma zaplodijo otroke. Toda ti otroci bodo vendar živeli med nami in $\mathrm{z}$ nami v skupnosti našega mesta. Kako naj razum in še posebej krščanska ljubezen dopustita, da rastejo nevzgojeni in postanejo strup in odpadek za druge otroke. Slej ali prej to uniči celotno mesto, kot se je zgodilo Sodomi in Gomori (1 Mz 19), Gibeji (Sod 20) in še mnogim drugim mestom.

2 Martin Luther, An die Radherrn aller stedte deutsches lands, das sie Christliche schulen auffichten und halten sollen (1524), v WA - Weimarer Ausgabe 15 (Weimar, 1899), 27-53. Gre za daljši Luthrov spis, odprto pismo, mestnim oblastem reformiranih mest, v katerem se po razpustitvi samostanov in samostanskih šol zavzema za novo, široko organizacijo šol in izobraževanja, z novimi humanistični$\mathrm{mi}$ in reformacijskimi cilji, vsebinami in metodami. Posebej govori o pomenu jezika/jezikov in skrbi za študij klasičnih jezikov, hebrejščine, grščine in latinščine, zaradi ohranjanja in razumevanja Biblije v izvirnih jezikih. Ta del je bil v slovenščino že preveden in objavljen v knjigi: Martin Luther, Tukaj stojim: Teološko politični spisi, uredil in prevedel Božidar Debenjak (Ljubljana: Krtina, 2002), 59-66. $\mathrm{V}$ naš izbor ga zato ne vključujemo. V izbor tudi nismo vključili daljše kritike dotedanjega izobraževanja v samostanih in obsežne Luthrove biblijske dokumentacije ter argumentacije za njegove kritike in zahteve. 
Drugič: velika večina staršev ne zmore in ne zna vzgajati in poučevati otrok. Sami se niso naučili nič drugega kot poskrbeti za želodec. Za dober poduk in pravilno vzgojo so potrebni posebni ljudje.

Tretjič: tudi če bi bili starši za to sposobni in voljni, zaradi drugih poslov in skrbi za hišo nimajo ne časa ne prostora, pa jih stiska sili, da najamejo za otroke skupne vzgojitelje ali celo posebnega samo za svoje otroke, če si to lahko privoščijo. A za navadne ljudi bi bilo to predrago in zaradi revščine bi bil tako marsikateri nadarjeni otrok zanemarjen. Mnogo staršev tudi umre in otroci ostanejo sirote. [...]

Zato so mestni svet in oblasti dolžne, da mladim ljudem posvetijo kar največjo skrb in oskrbo. Ker jim je vse mesto zaupalo dobrine, čast, telo in življenje, ne ravnajo odgovorno pred Bogom in svetom, če si po najboljših močeh noč in dan ne prizadevajo za dobrobit in napredek mesta. Dobrobit mesta pa ni le v tem, da zbira zaklade, da ima močne zidove, lepe hiše, mnogo topov in oklepov. Še huje, kjer je tega v izobilju, pa pride $\mathrm{v}$ roke norcev, je za mesto toliko slabše in škoda toliko večja. Za mesto, njegovo blagostanje in moč so najpomembnejši številni dobri, izobraženi, razumni, častni, dobro vzgojeni meščani; ti zmorejo potem zbirati zaklade in dobrine, jih ohranjati in dobro upravljati. [...]

Ker mesto potrebuje take ljudi in ker od povsod slišimo tožbe, da jih primanjkuje, ne smemo čakati, da bodo zrasli sami od sebe. Ne moremo jih izklesati iz kamna ne izrezljati iz lesa. Tudi Bog ne bo naredil čudeža, če si pri stvari lahko sami pomagamo z drugimi njegovimi darovi. Sami se moramo potruditi in zbrati sredstva, da jih vzgojimo in usposobimo. Kajti kdo je kriv, da so zdaj v vseh mestih sposobni ljudje tako na redko posejani, če ne oblasti, ki so pustile, da so mladi rasli kot les v gozdu, in jih ni zanimalo, kako bi jih učili in vzgojili? Zato je les tako grčast, da ni uporaben za gradnjo in je dober le za podkuriti.

Brez posvetnih oblasti ne gre. Toda ali bomo pustili, da vladajo samo še cepci in grobijani, če pa lahko poskrbimo za boljše? To bi bilo vendar barbarsko in nerazumno. Potem lahko naredimo za gospodarje kar svinje in volkove, da bodo vladali tistim, ki nočejo premisliti, kaj pomeni vladati ljudem. Prav tako je nečloveško in zlobno, če ne pridemo dlje kot do stališča: mi hočemo vladati, kaj nas briga, kaj bo s tistimi, 
ki pridejo za nami. Ljudje, ki mislijo pri vladanju samo na svojo korist in čast, naj vladajo svinjam in psom, ne pa ljudem. Tudi če si z vso vnemo prizadevamo, da bi za vladanje vzgojili same dobre, izobražene in usposobljene ljudi, bo še vedno dovolj muk in težav, kaj šele, če za to ničesar ne storimo.

»Da,« boš zopet ugovarjal, »če že moramo in hočemo imeti šole, kaj nam koristi učenje latinščine, grščine, hebrejščine in tako imenovanih svobodnih umetnosti. ${ }^{3}$ Za zveličanje nam zadostuje, da beremo Biblijo in Božjo besedo v nemščini.» Odgovarjam: da, žal dobro vem, da moramo mi Nemci vedno biti in ostati beštije in neumne živali, kakor nas imenujejo v sosednjih deželah, in to zasluženo. Čudim pa se, zakaj ne rečemo kdaj tudi: kaj nam bodo svila, vino, začimbe in druge tuje stvari, ko pa imamo sami v Nemčiji vina, žita, lanu,volne, lesa in kamna v izobilju, ne le za hrano, ampak za povrh še za čast in okras. Zaničevali bomo znanosti, umetnosti in jezike, ki nam niso $\mathrm{v}$ škodo, ampak nam $\mathrm{z}$ večjim ugledom, častjo, koristnostjo in prednostjo služijo pri razumevanju Svetega pisma in pri vodenju posvetne uprave. Ne bomo pa se odrekli tujemu blagu, ki ni za nas niti nujno niti koristno, pa še odirajo nas z njegovimi visokim cenami. Se ne reče temu po pravici: "nemški norci in beštije«? [...]

Že zato, da bi ohranili zunanji posvetni red, svet potrebuje dobre, sposobne moške in ženske. Moški morajo znati dobro vladati deželi in ljudem, ženske morajo skrbeti za hišo in služinčad in skrbno vzgajati otroke. Iz dečkov morajo zrasti taki možje in iz deklic take žene. Toda za to je nujno dečke in deklice dobro poučevati in vzgajati [...] Spet boš rekel: »[D]a, vsakdo lahko sam tako uči in vzgaja svoje otroke«. In spet odgovarjam: Lahko vidimo, kako se tako uči in vzgaja! In tudi če taka vzgoja kar najbolje poteka in uspeva, iz nje ne pride kaj več od malo bolj urejenega in spodobnega zunanjega obnašanja, v osnovi pa ostajajo klade, ki ne znajo ničesar povedati in ne zmorejo nikomer ne svetovati ne pomagati. Če pa mlade ljudi v šolah in drugod učijo in vzgajajo izobra-

3 Luther ima v mislih tako imenovane artes liberales, "svobodne umetnosti«, kamor so v srednjem veku prištevali (in v šolah poučevali) »trojček" gramatike, logike in retorike ter »četverček« glasbe, aritmetike, geometrije in astronomije. (Op. prev.) 
ženi in olikani učitelji in učiteljice, ki učijo jezike, zgodovino in druge znanosti, bodo slišali pripovedi in izreke iz vsega sveta, zvedeli, kaj se je dogodilo temu ali onemu mestu, cesarstvu, knezu, možu ali ženi. Tako bodo v kratkem času imeli pred seboj kot v ogledalu življenje in nehanje, načrte in nasvete, uspehe in neuspehe vsega sveta. Iz tega bodo sami zmogli lasten uvid in presojo ter se v strahu Božjem ustrezno vključiti v tok sveta; iz zgodovine bodo izvedeli in spoznali, k čemu je treba $\mathrm{v}$ tem zunanjem življenju stremeti in česa se izogibati, ter tudi drugim znali ustrezno svetovati in vladati. Domača vzgoja brez šole nas lahko izuči le na osnovi lastnih izkušenj. Toda preden bi na tak način dosegli modrost, bi bili že stokrat mrtvi, pred tem pa bi vse življenje nepremišljeno ravnali. Lastna izkušnja potrebuje mnogo časa.

Seveda morajo mladi skakati in tekati ali sploh početi nekaj, v čemer uživajo. Tega jim ni mogoče braniti; sploh ne bi bilo dobro, če bi jim vse prepovedovali. Zakaj jim torej ne bi pripravili šol in približali takih znanosti, ko pa je zdaj z Božjo milostjo vse tako urejeno, da se otroci lahko učijo z užitkom in igro, pa naj gre za jezike in druge znanosti in umetnosti ali zgodovino. Zdaj v šolah ni več vic in pekla s trpinčenjem $\mathrm{z}$ deklinacijami in s konjugacijami, ko se ob vsem tepežu, trepetu, strahu in stokanju nismo ničesar naučili. Če si vzamemo toliko časa in truda, da otroke naučimo igrati karte, plesati in peti, zakaj si tisti ljudje, ki to znajo in zmorejo, ne vzamejo toliko časa, da bi jih naučili branja in drugih umetnosti, dokler so mladi ter imajo čas in veselje za to. Zase lahko rečem: če bi imel otroke, bi se morali učiti ne le jezike in zgodovino, temveč tudi petja in glasbe in vse matematike. [...]

Moja želja je, da so otroci vsak dan uro ali dve v šoli, vsaj toliko časa pa delajo doma in se učijo rokodelstva ali česa drugega, oboje skupaj torej, dokler so še mladi in se lahko usposabljajo. Za kegljanje, igre z žogo, tekanje in ravsanje tako in tako porabijo desetkrat več časa.

Prav tako naj ima tudi deklica toliko časa, da gre za uro ali dve v šolo in vseeno opravi svoje naloge v hiši. Prespala, preplesala in preigrala bo gotovo več časa. Manjka le volje in odločenosti za to, da bi mlade vzgajali in $\mathrm{z}$ dobrimi ljudmi nudili svetu pomoč in nasvet. Hudič ima raje 
neobdelane hlode in nekoristne ljudi, da le ne bi šlo ljudem preveč dobro na zemlji. [...]

Ne le zaradi mladih ljudi, tudi zaradi ohranjanja obeh naših stanov, duhovnega in posvetnega, je skrajno nujno, da se te zadeve lotimo odločno in pravočasno, da nas ne bi kasneje - in prepozno - stalno grizla vest, ker smo najprej nekaj zanemarili, potem pa to morali opustiti, ker je bilo prepozno, čeprav bi sicer to radi storili. [...]

Žal smo bili predolgo v mraku pa smo zgnili in se pokvarili. Predolgo smo bili nemške beštije. Uporabimo končno razum, da bo Bog spoznal našo hvaležnost za njegova dobra dela in da bodo tudi druge dežele (u)videle, da smo tudi mi ljudje in da se zmoremo od njih kaj koristnega naučiti, ali njih same kaj podučiti, da bo svet boljši tudi z nami in zaradi nas. Jaz sem svoje storil. Hotel sem vsaj nemški deželi svetovati in pomagati, pa čeprav me zato nekateri zaničujejo in se požvižgajo na moje dobronamerne nasvete, ker da vse bolje vedo. Proti temu nič ne morem. Seveda vem, da bi drugi zmogli to bolje izvesti, toda ker molčijo, poizkušam sam, kolikor vem in zmorem. [...]

$\mathrm{Na}$ koncu pa morajo vsi, ki jim je v veselje in zadovoljstvo, da bodo $v$ Nemčiji ustanovili in vzdrževali take šole in jezikovno izobraževanje, pomisliti tudi na to, da se s trudom in $z$ denarjem ne sme varčevati tudi pri ustanavljanju dobrih knjigarn in knjižnic, posebej v premožnih velikih mestih. Da se evangelij in najrazličnejše znanosti ohranijo, morajo biti zapisane in ohranjene v knjigah in spisih. [...]

\section{VIR}

Luther, Martin. (1524) 1982. Offener Brief an die Ratsherren aller Städte Deutschlands, christliche Schulen einzurichten und zu unterhalten. V Martin Luther Taschenausgabe: Auswahl in fünf Bänden. Ur. Horst Beintker, Helmar Junghaus, Hubert Kirchner. Band 5, 208-234. Berlin: EVA.

Iz sodobne nemščine prevedel Marko Kerševan 


\section{Philipp Melanchthon Hvalnica šolskemu življenju, $1536^{4}$ [izbor odlomkov]}

Šolsko življenje zasluži najvišjo (po)hvalo, saj se v šolah ravna manj sofistično kot kjerkoli drugod in je prizadevanje poštenih ljudi usmerjeno edino k odkrivanju resnice. Je odslikava tistega blaženega stanja, v katerem so živeli ljudje v zlati dobi ali bi gotovo živeli, če bi ta zlata doba obstajala in bi človeške narave ne prizadela grešni padec in smrt. Ali ne bi bilo človeško življenje $\mathrm{v}$ tem primeru vesela šola, $\mathrm{v}$ kateri bi starejši in boljši poučevali svoje bližnje o verskih in prirodoslovnih vprašanjih, o nesmrtnosti duše, o gibanju nebesnih teles in vseh okoliščinah življenja? Stari in mladi bi ves svoj čas posvetili takim filozofskim vprašanjem in razpravam. Tako vsaj si jaz predstavljam življenje Adama in drugih izjemnih ljudi. Šolsko življenje je podoba tega nadvse srečnega/ blaženega stanja.

Po tem, ko sem povedal nekaj o nujnosti in koristnosti šolskega življenja, bi rad nekaj dodal še o njegovi svetosti. Nobena naloga ni Bogu bolj všeč, kot je proučevanje in razširjanje resnice in pravice, kajti to sta posebna Božja darova, ki omogočata najrazločneje spoznati njegovo navzočnost. Ustvarjena sta bila posebej zato, da bi z njima spoznali Boga in vse, kar je dobro; prav zato je treba zanju posebej skrbeti. V ta namen je Bog dal človeku jezikovno (spo)razumevanje. Nobenega dvoma ni, da je Bogu življenje kot poučevanje in učenje najbolj všeč in da imajo $v$ tem pogledu šole prednost pred cerkvami in knežjimi dvori, saj se $\mathrm{v}$ njih $\mathrm{z}$ večjo vnemo prizadeva za resnico. Kdor hoče živeti na način, ki je Bogu všeč, ta se ne bo umaknil v osamljenost; nobene druge življenjske oblike ne bo imel za bolj sveto, ampak bo ostal v skupnosti učečih: $v$

4 Philipp Melanchthon: De laude vitae scholasticae oratio (1536). Izvirno latinsko besedilo je v Corpus Reformatorum XI (Halle an der Saale, 1843), str. 298-306. Skupaj z nemškim prevodom (Rede vom Lob des schulischen Lebens) je v izboru: Philipp Melanchthon, Glaube und Bildung: Texte zum christlichen Humanismus, ur. Günther R. Schmidt (Stuttgart: Reclam), 204-209. Kot pri Luthru nismo vključili in prevedli obsežnega sklicevanja na Biblijo, je v tu uporabljenem viru izpuščeno Melanchthonovo sklicevanje na antične vzglede in avtorje. 
njej si bo prizadeval, da postane zaslužen za človeštvo in učil tudi druge, da se s tako dejavnostjo služi ohranjanju in razširjanju najvišjih dobrin. Podučeval bo dvomeče duše, seznanjal bo ljudi s pravom in z zakonom ter drugimi dolžnostmi, raziskoval bo bistvo stvari, zdravljenje bolezni, vzroke sprememb v naravi, gibanje in vplive nebesnih teles, pripravljal bo študirajočo mladino na višje fakultete, pojasnjeval bo zgodovinske vire in tradicije, pisno bo poročal o pomembnih dogodkih, pomnoževal bo sijaj umetnosti in znanosti. Kdor dela vse to, časti Boga na način, ki mu je všeč in postane zaslužen za človeštvo na posebej odličen način. Pripeva namreč k ohranjanju znanja, ki služi življenju in ga pospešuje, k oblikovanju človeške zavesti in zmožnosti presojanja, k ohranjevanju miru in zmanjševanju napak in slabosti javnega življenja. Ta življenjska oblika ne le da ima prednost pred samostanskim življenjem, temveč odseva Božje bistvo [sed vere divinum est]. [...]

$\mathrm{V}$ šole moramo vstopati enako kot vstopajo verniki v cerkev $\mathrm{k}$ molitvi, kajti tudi v njih imamo opraviti s svetim. Zelo skrbno moramo opravljati svoje svete dolžnosti, sicer bomo z malomarnostjo uničili znanosti in umetnosti. Dopustiti, da propadejo umetnosti in znanosti, ni manjša krivda od osramotitve obredov v cerkvi. [...]

Boljše ko je stanje v državi, velikodušnejša je država do tistih, ki služijo umetnostim in znanostim. [...]

Nič ni prijetneje, kot poslušati strokovnjake, ko govorijo o najpomembnejših zadevah, o raznolikosti narave, o državi, o oblikah religije. Obstaja star izrek: »Zunaj univerze ni življenja.« Govori o zadovoljstvu, ki ga nudi življenje v šoli. Izrek je gotovo nastal med izobraženci, ko so izkusili užitek, ki ga nudi medsebojna izmenjava misli in pogledov. [...]

Nadvse prijetno je skupno življenje in sodelovanje z izobraženimi in s pokončnimi ljudmi, ki spoštujejo moralna načela ter so premišljeni in zadržani pri svojem ravnanju in izražanju notranjih občutij. Zato ni bolj ponotranjenega in trdnejšega prijateljstva, kot je »filozofsko«, ki nastane med eruditi pri skupnem študijskem prizadevanju. [...]

Nanizal sem le nekaj primerov in razlogov, da bi mladi študenti razumeli in sprejeli smisel svojega načina življenja ter se zavedli, koliko skrbi in preudarnosti zahteva od njih, da bi mu bili v čast. 
Učenjaki so privzdignjeni v vrh človeških zadev. Svojo nalogo - ki je med vsemi najtežja - lahko opravimo le, če se poučevanju posvetimo z vso vnemo. Ohranjanje in razširjanje znanosti, ki služijo življenju, je najbolj sveta in Bogu najbolj všečna dejavnost. Zato moramo vedeti, da bo Bog klical na odgovornost tiste, ki s svojimi slabim načinom življenja šolo sramotijo in ničesar ne prispevajo k ohranjanju znanosti. [...]

\section{VIR}

Schorlemmer, Richard ur. 2008. Was protestantisch ist: Große Texte aus 500 Jahren. 269-271. Freiburg: Herder. Izbor odlomkov in sodobni nemški prevod latinskega besedila po Hans-Rüdiger Schwab, ur. 1997. Philipp Melanchthon: Der Lehrer Deutschlands; Ein biographisches Lesebuch. München: DTV.

Iz nemščine prevedel Marko Kerševan 